\title{
Beyond practical dilemmas and conceptual reductions: the emergence of an 'accommodative consciousness' in the alternative globalization movement
}

\section{S. A. Hamed Hosseini, Australian National University}

A simple survey of participant groups and organizations in the recent mobilizations against the neo-liberal corporate-led globalism, generally known as the anti-globalization movement, can show that many supposedly contradictory orientations have contributed to the field of resistance. Groups of reformists and revolutionaries, localists and universalists, identitybased and ideologically motivated initiatives, particularists and universalists, communitarian and pluralists, modernists and postmodernists, together have structured the multitudinous nature of the global resistance against neo-liberal policies, international leading organizations such as the World Trade Organisation (WTO) and the new imperialist developments (Starr 2000). However, what needs examining is the movement's potential for new perspectives that imply a progressive accommodation between the contradictory orientations in alliances and solidarity networks. Initial manifestations of such potential have come into view in recent protest events in the form of coalitions, solidarity networks, affinity groups, in the growing number of social and online forums, and in the form of networking and exchanging ideas aimed at developing alternatives to the current capitalist globalization forces.

As this article argues, these growing manifestations in the anti-globalization movement can hardly be understood in terms of mainstream approaches in social movement studies. Rather, scholars are required to reassess dominant lines of theoretical controversy-rooted in the division between the so-called new social movements and old social movements - as means of understanding current global movements and their historical context. They are also required to set up efforts to characterize global movements in terms of the possibilities that 
these movements themselves are endowed with, in order to synthesize their practical orientations. Many theoretical and intellectual controversies over the cognitive nature of the post-1960s democratic movements have persisted unresolved and extended into arguments about the characteristics of global social movements. Table 1 represents the ideational attributes of the current global social movements in the form of ten extracted polarities around which both the controversial academic description of the movement and the ideological trends are constructed.

Table 1: Lines of controversies about the cognitive features of the post 1970s democratic movements ${ }^{1}$

\begin{tabular}{|l|l|}
\hline \multicolumn{2}{|l|}{ The bipolar axis of description in current social movement studies } \\
\hline Soft Praxis & Hard Praxis \\
\hline More subjective in orientation & The communal, collective \\
\hline The individual & Redistribution \\
Recognition & The political, public \\
The personal, private & Revolution, Abolition \\
Reform & The global \\
The local & Solidarity, unity, certainty \\
fluidity, diversity & Ideology, emancipatory \& strategic \\
Identity, life-style politics & politics \\
The social-cultural & The political-economic \\
The postmaterial & The material \\
The particular & The universal \\
\hline$\leftarrow$ & \\
more agential and & more structural \\
more post-modernist & and more modernist \\
& \\
\hline
\end{tabular}

As the table shows the ten polarities or the bipolar continua of controversy about the cognitive features of recent movements can be summed up in a general axis that I label as the axis of soft praxis-hard praxis. Soft praxis includes those features that are more subjective and agential in nature, such as being more identity-based, self-recognition based,

\footnotetext{
${ }^{1}$ These are at the same time the polarities around which the modes of in-praxis thought are constructed. In order to make it easier for readers to follow the argument around the dichotomic concepts, they are all typed in italic throughout this article.
} 
postmaterialist, or being more cultural rather than being more materialist, resource-oriented, or political-ideological in orientation. All these polarities have shaped the main lines of controversy between the scholars influenced by the culturalist turn in social sciences, on the one hand, and those who have retained structuralist approaches over describing the post1960s democratic movements, on the other. ${ }^{2}$

Despite their contrasts, the new social movement (NSM) approach, post-modernist perspectives, and social constructionism have provided a subjectivist-culturalist shift in social movement studies since the 1970s. The common feature among these subjectivist tendencies is that they consider an historical discontinuity or a paradigmatic shift between two phases of modernity, or in the case of post-structuralism, between modernity and post-modernity. They argue that this historical shift has happened in modern society as a whole, that is, a new totality has taken place, which implies new ways of theorizing its social forces. Albeit with different emphases on the polarities, the scholars influenced by the culturalist shift have argued that the recent movements, including the anti-globalization movement, should be categorized as soft praxes, rather than hard praxes, in dealing with the new totality of modern society (see Melucci 1995; Melucci 1996; Melucci and Avritzer 2000; McDonald 2002; Castells 2004; Farro 2004).

For instance, for Melucci (1989; 1996), the newly emerging totality is the 'semiotic aspects of a postmodern information society' and the numerous ways in which these elements are reflected in an increasingly individualized context of activism. For the early Castells (1983), this structural transformation during the 1970s is summed up in the capitalist transformation of urban space alongside the state's role in collective consumption. Nonetheless, for the late Castells (1997), the shift during the 1980s-1990s is the emergence of the 'network society' in which information production increasingly dominates the production of wealth and free capital from restraint. For Habermas (1984; 1987), there is a principal tendency in advanced capitalist political economy to instrumentally dominate the communicative lifeworld. Therefore, his understanding of the post-1970s' movements is more concerned with their potential in defending the lifeworld which is essentially cultural and intersubjective in nature.

\footnotetext{
${ }^{2}$ Although scholars have shown different emphases on the polarities, I deal with them equally since the unit of my review is not personal views but the metatheoretical paradigms, i.e. the soft and the hard praxis.
} 
And, for Touraine (1971; 1981; 1985), it is the post-industrial programmed society as a new context in which social movements challenge authorities for control of knowledge and information. Touraine claims that there is a central contradiction for each social formation and accordingly there is one predominant social movement (SM) in response to the contradiction (see Touraine 2000).

This postist orientation towards soft praxis, drawing on the participation of identity-based and particularist movements in the global field of resistance, has finally entailed overemphasizing fluidity, subjectivity, diversity, individuality, and particularity. Such an ideological shift may be seen not so much as an overthrow of rationalist approaches, but more as a switch from the 'objective' to the 'subjective' pole within the core dualism of Western modern thought (see Tew 2002: 22). In contrast to the culturalist approaches, however, some scholars by drawing on the cosmopolitanist and rationalist trends within the diverse global field of resistance attribute the hard praxis characteristics (Table 1, right column) to the current global movements. Though with different emphases on different hard praxis attributes, they believe the movement is better characterizable as ideology-based, political, universalist, emancipatory and redistribution-oriented (see Della Porta and Kriesi 1999; Cohen and Rai 2000b; Laxer 2001; Busby 2002; Chase-Dunn 2002; Burgmann 2003; Johnston and Laxer 2003).

\section{From 'anti-globalization' as a label to 'alter-globalization' as an ideal-construct}

Despite the abovementioned dualist arguments, the newly developed perspectives inside the global field of resistance convey a new mode of social thought, coined here the accommodative cognition. In this article, in order to overcome the difficulties of examining the whole diverse global field of resistance for its newly evolved ideological elements, I start by constructing an ideal-type of the so-called anti-globalization movement. The ideal-typical description of the movement is constructed by accentuating those notions of the movement which cannot be easily understood based on dominant theoretical frames. I call this idealconstruction the alter-globalization movement, which can be used as an analytical tool to examine different participant groups, organizations, individuals, and intellectuals within the global field of resistance for the novelty of their styles of thought. 
What I mean by alter-globalization is an ideological trend within the current global resistance to redefine globalization in an alternative way. Alter-globalization, therefore, attempts to rebuild global governance and transnational relations not just through institutional reforms but also, and mainly, through the plural participation of grassroots from below in transnational solidarity networks. It aims to put the totality of globalization on a genuinely democratic track. It has some features analogous with both identity politics and cosmopolitanism. Like cosmopolitanism, it consists of a type of internationalist ambition. However, it is not based on a proposition of the possibility of one single emancipatory subject (like the working class), one conflict, one universal alternative, or even one institution-based reformist model for the increasingly complex world. Neither is it based on an ignorance of localities and people's identities on the ground.

Universalist demands are particularly associated with the socialist movement. However, some new forms of universalism are recently re-articulated by scholars such as Held (1995; 2003; 2004), McGrew (1997), Falk (1993; 1997; 2000), and Holden (1999) and the think tanks of liberal internationalism, like the Commission of Global Governance. ${ }^{3}$ Based on these political demands, the movement should put pressure on international institutions to merge towards reforming their structures based on a moderated social democratic model, as in the case of ATTAC. In contrast, the particularist strands have mainly reconstructed their resistance against uneven globalization based on particular/local concerns.

The particularist trend is a desire to resist globalization processes with hegemonic or homogenizing dispositions, by publicizing them as devastative for specific identities and civil rights, such as women's reactions to the organization of workplaces in the global south, or homosexual reactions to the far right initiatives associated with neo-liberalism. At the same time, it is a desire for particular-local concerns, such as the ecological concerns about the impact of international trade agreements on the environment, job security, employment, and

\footnotetext{
3 'In January 1995 the Commission on Global Governance (1995a; 1995b) published its report on how to strengthen and reform global governance in order to manage global affairs in response to the security needs of all people and the planet rather than the needs of states only. According to the Commission, the UN will have to play a vital role in future global governance. Most of the proposals thus focus on reform of the UN system. However, observers agree that no matter how overdue reforms are, the Commission has failed to put any of its reform proposals on the political agenda' (Steen and Tryggestad 1996, 85). Falk criticizes the report as falling 'between two stools: it is too reformist and populist to appeal to elites, but it is not radical enough to satisfy activists in global civil society’ (Falk 1995, 563).
} 
health issues in a particular region. This sort of resistance introduces some alternative ideas but not as comprehensive as the globalization process. Therefore, the particularist projects tend to be particularistic in substance although transnational in structure, as in the case of Jubilee 2000 and the International Campaign to Ban Landmines. Most of the contributions to recent global resistance by so-called NSMs, or their legacy, can be categorized as the bearers of global particularism when they reconstruct and rearticulate their collective identities, concerns and democratic orientations in relation to recent global changes ('think global, act local').

However, the alter-globalization mode of contention does not see an indispensable antagonism between universal norms and particular demands for autonomy. Similarly, the alter-globalization trend does not consider antagonism between other dualist orientations such as unity/diversity, material/postmaterial, socio-cultural/political-economic, local/global, communal/individual, identity/ideology, private/public, reform/revolution, lifepolitics/emancipatory-politics, and recognition/redistribution.

The assumption of antagonism between these interrelated dichotomies had been dominant in both post-1970s social activism and sociological theories in differentiating between new and old social movements. During the 1990s, many and various movements-including environmental, women's and indigenous people’s movements-started creating transnational affiliations and exploiting sources of transnational leverage. Through these processes of transnationalization, the movements opened a new scope for transcending the dualities between local and global, and universal and particular. This is a specific form of logic based on which local autonomy and universal norms are not seen as contradictory (for some exemplary cases in this stage of transformation, see Carr 2002; Goodman 2002; Grenfell 2002; Sales 2002).

However, the outcome of such conversion can be interpreted as a process of reconstructing particular concerns in relation to global issues rather than a significant evolution in the basic assumptions of cognition. The alter-globalization trend has developed since the late 1990s out of such paradoxical experience of transnational coalitions around particular concerns and their particularist failures in addressing the systemic problems. It can provide a challenge to all predominant modes of social knowledge. The trend, as I will discuss, has a strong 
cognitive capacity to develop a new historical subjectivity that is able to balance the dualities and inclusively accommodate lines of social polarization such as class, gender, race and so on in systemic interpretations of global complexities.

The cognitive elements of this new mode of subjectivity-consciousness can be found disparately among analytical and normative discourses raised by the movement through both confronting the current processes of globalization and contesting the retroactive forces of resistance, i.e. particularism and cosmopolitanism. Those who evidence such a mode of knowledge usually call for democratization at both the local-community and the global levels. There are common and universally confirmed themes such as solidarity, co-operation, consensus, affinity, openness, autonomy, equality, participation, and diversity among wellidentified identities (Ashman 2004, 148-9). At the level of social consciousness, as Köhler and Wissen say of the urban branches of the movement, 'while criticizing and acting upon very local/material urban issues, they often explicitly relate and politicize these issues in a broader context and articulate their criticism on various spatial scales—not only on a local but also on a global scale’ (2003, 943).

There are also other strong continuities between the movement and the particularist trend, in terms of their anti-authoritarian, self-determinist, and autonomist perspectives. However, the movement is a field for building consent and coordination among differential and fragmented goals. The alter-globalization movement has shown a systemic consciousness about social problems, by attributing them to the endogenous and inherent features of current social organization. Yet, it is awkward to expect the emergence of any single comprehensive political programme for systemic change that will create a clear anti-systemic consciousness at a massive level, as is anticipated by Fotopoulos (2001) and others.

The label, alter-globalization, in this article, also roughly refers to the whole global resistance, since the present field of ideational contention will be better identified with its newly proactive prospect in challenging dominant reductionist modes of thought. In addition, the movement has entered an affirmative stage ('another world is possible'), whether with reformist or radically transformative proposals. Although it is impossible to identify the alterglobalization trend as a unified, independent, and consolidated movement, there are 
significant signs of an evolving accommodative mode of cognition among various initiatives that are beyond pragmatic alliances against a common enemy. The features/dimensions of this mode of thought that determine its 'accommodative' or 'synthetic' nature are as follows:

1. Transcending the polarity of soft-praxis/hard-praxis and its associated intellectual dualisms - that are rooted in the 1970s-1980s' controversies between modernists and post-modernists, structuralists and post-structuralists, and Marxists and post-Marxists.

2. Going beyond the incompatible conceptions of social differentials-around issues like gender, race, cultural identity, individuality, and community_-in establishing a flexible solidarity based on a collaborative inclusion of the Other into the definition of Self.

3. Understanding the complexity of globalization processes, and the world system in terms of their unevenness, contradictions, and multidimensionality: this is associated with a systemic conception of particular events in relation to the main globalization processes without overlooking their specific socio-cultural contexts.

\section{The Alter-globalization Movement: beyond or between hard and soft?}

Concerns about the paradoxical nature of the current global field of resistance are not restricted to academic arguments. Similar to abovementioned academic debates, the concerns are explicitly reflected in the form of dual concepts within a variety of activists' descriptions of the whole movement. Is the movement wandering between these paradoxes or able to go beyond them by inventing new practical models and concepts? The activist editors of the book The World Social Forum: Challenging Empires vigilantly pose a question about whether a new internationalism is taking place, and whether such an internationalism could be based on a 'plural global solidarity' (Sen, et al. 2004, 1). Thomas Ponniah and William F. Fisher (2003, 8-9), two American academic-activists, analyzing the 2002 conference documents of the World Social Forum (WSF), derive five contradictory orientations within the field: 'revolution versus reform', 'environment versus economy’, 'human rights versus protectionism', the 'universality of values versus cultural diversity', and 'local versus global.' 
Such concerns are also normatively reflected in the alternative solutions drawn by activists. The activist Carola Reintjas introduces Solidarity Economy, as discussed in a set of workshops in the third WSF, as an accommodation between contradictions. 'Solidarity Economy designates all production, distribution, and consumption activities that contribute to the democratization of the economy based on citizen commitments both at a local and global level. Solidarity Economy is a dynamics of reciprocity and solidarity which links individual interests to the collective interest' (Reintjas 2002, my emphases).

Hilary Wainwright, an activist veteran of the late sixties, compares the global movement with both the so-called old and new social movements. As she declares, the global movement is tackling the problems that defeated the post-1960s movements, like feminism and environmentalism. For her, the common cognitive features between the global movement and the movements of the 1970s-1980s — in contrast to the old labour movements — can be summarized as understanding the importance of practical knowledge and transformative power of the people organized from below. This is a shift from considering structured relations — such as political-economic institutions - as the major sources of social change towards considering human agency itself as the premium basis (see Wainwright 2004, xviii).

However, for the alter-globalization trend, in contrast with the 1970s-1980s movements, the organizational challenge is more related to the modes of sharing the abovementioned knowledge and power of creativity across all groups. Therefore, different new horizontal networking initiatives for sharing knowledge and experience have been invented, and still more need to be created. Yet, what is obvious is that this situation has resulted in the emergence of a broader conception of alliance among activists. At the same time, many groups, in order to preserve the openness of opened spaces, attempt to ground these organizational structures in the principles of a deeper, participatory democracy.

In sum, the alter-globalization movement has incorporated many of the orientations and practices of radical 1970s-1980s movement activism. However, the capacity of the movement to imagine the interconnection between different social issues at different levels of reality has resulted in the emergence of a new project to oppose capitalism. This project resembles the original demands of early labour and anarchist movements before WWI which was abandoned mainly after WWII by the social democratic compromise of labour and capital, 
until the recent retreat of the welfare state in the 1980s (see Burgmann 2003 for the incorporated labour elements; and see Day 2004 for the subsumed anarchist logic of affinity).

The other feature of the alter-globalization movement is its special strategy in changing prevalent political and economic institutions, which is beyond the dilemma of revolution and reform. As the possibilities of both revolution and reform have been exhausted, practices of structural renewal are being implemented by some of the most energetic movements involved in the global field of resistance (Day 2004). Following Gorz (1967), one may call it a ‘revolutionary reform’ or ‘non-reformist reform’ (referenced by MacEwan 1999, 15).

For academic-activist Peter Waterman, both reformist and radical trends need to accommodate each other in the context of current global resistance (2003). Eschle points out that the global democratic schemes developed out of recent resistance have offered 'an alternative to both reformist complacency and the revolutionary model of change, one that aspires to transform social and political structures through complex processes of societal selforganisation’ (2002, 331). In early protests like those of Seattle 1999 and Washington 2000, the slogan 'Fix it or Nix it' gained popularity, meaning that international financial institutions like the WTO must either change their ways by addressing non-trade issues like human rights, or be abolished (Healy 2000). Such slogans might seem a catch-cry or a strategic choice facing the movement, but as Munck (2003) mentions, they convey an 'all or nothing' perspective. Instead, fundamental reforms in global rules are needed to facilitate the emergence of alternative institutions. For Unger, 'reform is radical when it addresses and changes the basic arrangements of a society: its formative structure of institutions and enacted beliefs’ (1998, 18-9).

Adler and Mittelman (2004) in surveying protesters' attitudes about reforming or abolishing the international financial institutions (IFIs), find that many protesters believe that both the reformist and abolitionist positions are bound up with a broader protest against capitalism and US policy. Most prefer to describe their reasons for joining the protest in terms of overall 'ends’ like a 'democratic, just and ecologically sane economy', rather than in terms of 'means' like reform or abolition. However, when they are forced by the interviewer to choose between reform and abolition, just 6 percent identify the abolition and 20 percent identify the reform of IFIs as the main reason. 
In contrast to both reformism and revolutionism, the alternative orientations raised by the alter-globalization movement focus on building parallel independent institutions not only for organizing actions but also for articulating new ideas, establishing democratically executable political-economic projects and alternative media. The first WSF in Porto Alegre itself was established as a parallel event at the same time as the World Economic Forum meeting in Davos, Switzerland. By stressing the 'social' rather than the 'economic', the 'political' and even the 'political economic', the forum gives priority to those aspects of life that have always been reduced, if not totally ignored, in rationalist and neo-liberalist interpretations of social life. The 'social' cannot be as easily divided into private and public as the political and economic have been divided so far in dominant discourses. The other outstanding instance is the Independent Media Centre (Indymedia), ${ }^{4}$ which is a network of collectively run media outlets, established in 1999 by various independent and alternative media organizations. It now has branches all over the world's major cities in parallel to corporate media. Discussing the reemergence of the anarchist logic of affinity among the youngest forces of the alterglobalization movement, Day summarizes the key element of such logic as follows:

A desire to create alternatives to state and corporate forms of social organization, working 'alongside' the existing institutions; proceeding in this via disengagement and reconstruction rather than by reform or revolution; with the end of creating not a new knowable totality (counter-hegemony), but of enabling experiments and the emergence of new forms of subjectivity; and finally, focusing on relations between these subjects, in the name of inventing new forms of community. (2004, 740, my emphasis)

The antagonism between the politics of emancipation or total liberation, attributed to the movements in the era of modernism-industrialization, and the politics of life style or local resistance is also questionable, regarding the current forms of cognitive resistance and the evolution of the concept of emancipation itself. Pieterse shows that although emancipation dates from the Enlightenment through appeals to freedom and equality, progress and reason, it has been reconstructed and redefined in a diversity of projects even during the culmination of new social movements and postmodern theories. Reason, equal rights, liberal ideas, religious thoughts, history and self-determination are among sources of emancipatory movements (see Pieterse 1992, 16-7).

\footnotetext{
${ }^{4}$ Its website address is: www.indymedia.org .
} 
The concept of emancipation is the subject of consideration inside the intellectual field shaped around global resistance. According to the 'Reinventing Social Emancipation’ website, an international research project defined by a scholar-intellectual network: ${ }^{5}$

The paradigm of social emancipation developed by western modernity is undergoing a deep and final crisis. Social emancipation must, therefore, be reinvented. It must be understood as a form of counterhegemonic globalization relying on local-global linkages and alliances among social groups around the world which go on resisting social exclusion, exploitation and oppression caused by hegemonic neoliberal globalization. (Reinventing Social Emancipation Website 1999)

For Waterman, the concept of 'emancipation' is still relevant especially in a self-reflective manner to free 'Ourselves', as the subjects of the process we are trying to project, from our history and old paradigms, such as the emancipation of labour internationalism from trade unionism, socialism and Marxism. Therefore, hegemonic neo-liberal globalization as an external factor is not the only source of subjugation. While in both reformist and revolutionist paradigms problems are defined as externally oriented, the accommodative definition of emancipation is more transformative and self-reflective.

Another feature of accommodative cognition is the pluralistic reconciliation between material interests and moral (so-called post-material) values. Many of the issues that emerged in the post-Cold War era are constructed in relation to the biased processes of globalization, the rise of economic interdependence, and globalist ideological values (see Busby 2002). The resistance against neo-liberal globalization is not a self-interested class movement; nor is it for the sake of its participants' particular styles of life (Alfaro 2004). Rather it is a massive struggle against all unequal and homogenizing global relations of power that have aimed to suppress a variety of both material interests and life-styles. Hence, such a resistance could be interpreted as a massive struggle by the variety of identities and interests to save diversity itself, whether bio, cultural or social, as an actual norm and even a natural endowment.

The multi-scalar nature of globalization processes and the asymmetrical interrelations between the scales or levels_-local, national, regional, and global_-are acknowledged in many analytical and strategic accounts expressed in the field. The call for equality and justice between localities by the alter-globalization movement is also a call for ending dissonance

\footnotetext{
${ }^{5}$ See http://www.ces.fe.uc.pt/emancipa/en/ .
} 
between the scales due to the unjust exchanges of resources and unequal distribution of income. Munck (2003) argues that it is necessary to move beyond the simple binary opposition of 'globalization from above' versus 'globalization from below' or the even simpler 'global=bad, local=good'. Not only do these conceptions entail a geographical fetishism but they also imply 'levels' in society in a way that is quite disabling.

Santiago (2004), a Filipino feminist activist, calls for more attention to the issue of 'structure', i.e. organizing participants into more protractile organizations, in the WSF (2004: xvi). According to her, activists must not be so concerned with their own use of power that it goes against diversity. Such a demand for the structuration of an open space requires a compromise between the fluidity of networks and the structural stability of the whole movement. Post-anarchist activist Ezequiel Adamovsky (2005) argues that the movement has reached a crossroads. It needs a new political focus, i.e. inventing 'institutions of a new type' that embody not hierarchies of power but cooperation among equals.

The Commoner, a new autonomist Marxist-libertarian web journal, ${ }^{6}$ which has developed new conceptions of 'common', 'enclosure' and 'community', with regard to the contemporary capitalist globalization processes argues for the relevance of these concepts in addressing current hegemonic processes and oppositional forces. ${ }^{7}$ The initiators of the journal, known as Commoners, who have been active in the European Social Forums, do not see a contradiction between their new conception of community and individual subjectivities, whereas both the particularity and universality of the conditions are reserved in this conception. Franco Barchiesi (2003), a Commoner, distinguishes between 'progressive’ and 'regressive' uses of the concept of community in the context of globalization. The retrogressive sense of community is grounded on authoritarian and exclusionist values, imposing a homogeneity that necessarily associates any vision of the local community defined as a mere opposition with the global.

De Angelis, a London-based Italian academic behind the Commoner, defines an alternative definition of community as 'social networks of mutual aids, solidarity, and practice of human

\footnotetext{
${ }^{6}$ The Journal is an Italian Edited but English language free access online journal on: http://www.thecommoner.org.uk .

7 'The very concept of community can still be a useful tool of analysis in spite of all its limitations' (Barchiesi 2003).
} 
exchange that are not reduced to the market form' (De Angelis 2003, 1). As he emphasizes, the place of these networks does not need to be bound to locality, but such communities can operate both in local and through trans-local places. Many social practices using modern communication technologies create trans-local spaces in which communities operate to complement local places. Therefore, in this definition of community, the public and private spheres of life, and individuality and collectivity are not regarded as contradictory polarities, since they are linked in human interactions around 'commons'. As is obvious, these conceptions of 'community' and 'common', regardless of critiques about their plausibility and validity, differ from static and traditional definitions. These theorized 'communing collectives' in the context of global resistance, named as communities by Commoners, are considered as real social agents of change which are as individual as they are collective, as local as global, and as personal as political. In some, underlying accommodative consciousness and solidarity is a new general Weltanschauung in which reductionist modes of thought are renounced.

\section{Accommodating the Other: beyond fragmenting conceptions of social divisions}

The social divisions of class, gender, ethnicity, race, nationality, sexual orientations, etc. lie at the very heart of today's societies (Anthias 1999). They are central in socio-cognitive constructions of relations between Self and Other and thereby in structuring socio-political solidarities. In turn, the mode of solidarity experienced among participants can influence processes of constructing their identities and their conception of otherness. Therefore, understanding the way individuals and groups conceptualize their relations with othersespecially alongside the socially constructed and conditioned differences - is important to configure the mode of solidarity they create across their differences.

The second dimension of the cognitive transformation revealed by the accommodative tendencies is related to such an aspect of constructing cross-identity solidarities. The expansion of communication among social subjects with different identities and the growing interdependence of social inequalities due to globalization processes have caused more complications in relations between Self and Other. These complications may cause uncertainty and thereby antagonism (as in the case of fundamentalist and racist 
particularisms) through the 'dogmatization of difference' (Connolly 2002). However, they can also facilitate flexible solidarities through the expansion of the Self's moral constitution to include the Other's concerns and interests against shared structures of disempowerment, without dissolving otherness (as in socialist and liberalist cosmopolitanism).

Regarding current cases of transnational solidarities, the endogenous conception of identity articulated around social divisions may no longer be the most crucial motivating and organizing principle for movements in responding to globalization as a looming multidimensional phenomenon. Amory Starr (2000), considering anti-corporate movements in a very broad scope, speculates that recent movements confront corporations on many fronts at once and they recognize allies with different identities with the same feelings of oppression. As a result, they centre the idea of multiple oppressions in their analyses of the enemy and in their visions of rebuilding the world. They also usually establish allies and define their enemies in ways that do not depend on identity as the basis of understanding and allies in ways that do not depend on a subtle and fragile 'politics of difference' (see Starr 2000, 166-7)

Ulrich Beck declares that, in the second age of modernity, categorical principles like collectivity, territoriality, and identity are being challenged (Beck 2000a, b). This suggests that these principles will be the subjects of two treatments: de- and/or re- construction. Globalization blurs and suspends boundaries and therefore implies revisions for defining identity. Integrative approaches have to consider these situations seriously in studying collective identities and contemporary social movements. Identity-based social movements have two options before them: reactively insisting on the boundaries, or proactively redefining their relationship with other identities and with the system as a whole. The latter option requires developing oppositional consciousness which critically addresses any form of oppression developed in conjunction with any social polarity like gender, class, race, ethnicity, and so on (see Dixon 2001, 15).

With different points of view in their published and online documents, the alter-globalization activists attempt to redefine corporate-led or capitalist globalization in terms of gender, race, or class relations. How are women, indigenous people, workers, and communities being exploited in the processes of uneven globalizations? How do these social groups typically 
defend their rights and resist? These are the main questions raised and answered in the collections of activists' articles that have been published in growing numbers of edited books or in open access magazines/journals like $\mathrm{Z}$ magazine ${ }^{8}$ and The Commoner. $^{9}$ Starhawk, an activist and award-wining author, who has been active in peace, direct action, ecofeminist and global justice movements for thirty years, in her article calls for encompassing the whole axes of oppression in the analysis of the system (see Starhawk 2004, 49).

In the same collection of articles (edited by Solnit 2004), Elizabeth Martinez (2004), a postanarchist academician, defines globalization from an anti-racist point of view. For her, the main victims of global economic integration are the nations and people of color as shown by the vast increase in migrant labor. Studying the demographic structure of transnational migrations simply evidences the interconnection between race, gender and class (Martinez 2004). By stressing the 'communal control of means of subsistence' as the basic notion in understanding current global class struggles, Midnight Notes Collective—an originally Marxist activist group — extends its vocabulary to enclose all sorts of social-economic enclosure and exploitation in capitalist globalization (Midnight Notes 1998; Midnight Notes Collective 2004).

As Roman and Arregui depict the Zapatistas' movement: 'With neo-liberalism as the clearly defined enemy, the movement constantly opposed multiple oppressions such as race, gender, and sexual orientation, while emphasizing the centrality of economic exploitation and the crucial role of workers in the struggle against neo-liberalism’ (1998, 133, 139, cited by Burgmann 2003, 242). Michael Hardt and Anthony Negri, two renowned figures on autonomist Marxism and the authors of a very influential book, Empire, claim that the left needs to leave behind outdated concepts like the proletariat and working class as the main forces of change, which vastly oversimplify the gender, racial, ethical, class diversities of today's world. Instead, they propose the term 'multitude' to capture both communality and singularity of those who stand in opposition to the wealthy and powerful. The constituent power of the multitude relies on its unique structure; the multitude involves communities of

\footnotetext{
${ }^{8}$ http://zena.secureforum.com/znet/zmag/zmag.cfm

9 http://www.commoner.org.uk/
} 
various types working together in a circulation of versatile struggles that are simultaneously against capitalism and for the construction of an alternative to it.

The Black Radical Congress (BRC), an organization sparked in 1998 in the US by black activists and scholars to rebuilt Black radicalism against neoconservative political and economic programs, introduces its mission on its website as follows:

Recognizing contributions from diverse tendencies within Black Radicalism — including socialism, revolutionary nationalism and feminism - we are united in opposition to all forms of oppression, including class exploitation, racism, patriarchy, homophobia, anti-immigration prejudice and imperialism.... We must see the struggle in global terms.... We need to meet people where they are, taking seriously identity politics and single issue reform groups, at the same time that we push for a larger vision that links these struggles. (Black Radical Congress 1999, webpage)

Salleh (2004), an academic and community activist, talks about the 'meta-industrial worker', as today's appropriate 'agent of history'. For her, recognizing the workers that constitute the majority of workers in the $21^{\text {st }}$ century global capitalism as a new class is based on stressing the systems of reproduction besides those of production. Therefore, this concept avoids being restricted to white male workers, but rather accommodates other victims of social polarizations, such as householders, farmers, and even hunter-gatherers. The more actors with different social backgrounds are experiencing common predicaments, the more likely the cross-boundary nature of social problems will be translated into identity (re)formation and the accommodative mode of knowledge. By cutting through the socially constructed polarities around gender, race, class, status, ethnicity and so on, the alter-globalization trend shows a cognitive capacity to resolve the Self/Other dualism and thereby other associated oppressive dualisms such as individual/collective, private/public and difference/equality. This capacity can be achieved through rejecting any privilege given, theoretically and/or practically, to difference over those things that people have in common and vise versa (Solomon 2002).

\section{Towards systemic conceptions of globalization and its complexities}

The third idealized aspect of the accommodative mode of consciousness is the growing tendency to develop multidimensional and systemic conceptions of global complexities, including the asymmetry and unevenness of globalization processes. Arguments around the 
newness of the post-1960s democratic movements have increasingly been replaced with the description of recent movements as 'global' and 'transnational' (Cohen and Rai 2000b). Global social movements (GSMs) are defined as 'conscious efforts to build transnational cooperation around shared goals that include social change' (Smith 1997, 59; Keck and Sikkink 1998; see also Cohen and Rai 2000a; O'Brien, et al. 2000). ${ }^{10}$ It was believed that these movements could be very influential by developing a plural 'global civil society' and thereby influence public opinion around different challenging issues, such as women's or environmental issues, at a global level (see Falk 1997; 2003). However, these trans-nationally shared efforts, during most of the last two decades, remained non-systemically restricted to some specific goals like reconstructing differential identities in a global problematic, whilst articulating central concerns across borders-for instance, the women's transnational networks, the peace/anti-nuclear and human rights networks, and environmentalist networks (for some cases see Sturgeon 1999; Moghadam 2000). But very soon, this inter- and transnationalization of resistance opened new visions and new spaces of exchanging experiences in confronting the global agents of disempowerment and subjugating global structures.

The mobilization of economic and cultural capitals on an increasingly uneven global scale has forced a number of activists to move beyond the specific and fragmented origins of identity, concern, and interest. As Callinicos (2003, 15) mentions, recent transnational movements are motivated by a sense of the interconnection between an immense variety of different injustices and dangers. Besides, as David Held and Anthony McGrew argue (2002, Ch. 5), the present era of globalization marks a shift towards a system of multilayered regional and global governance, with key supranational, intergovernmental and transnational bodies of authority such as G7, WTO, IMF, EU, World Bank, APEC (Asia-Pacific Economic Cooperation), NAFTA (North American Free Trade Agreement) and so on.

According to both moderate and radical intellectual arguments in the resistance, these bodies have enforced the rules of globalization, in undemocratic and irresponsible manners, which give advantages to the transnational corporations and the economic concerns defined by the

\footnotetext{
${ }^{10}$ Transnational activism against neoliberal globalism is nothing new (Rucht 1999). Neither are international solidarities and alliances across borders (Routledge 2000). Yet, only since the late 1990s have scholars in SM studies made important efforts to understand the recent advancements in transnational mobilizations and solidarities.
} 
ruling class over the social rights and environmental concerns of citizens (see for example, George 2001; Cavanagh and Mander 2004). The new rules also, on a global scale, privilege the interest of citizens of those nation-states that host the bulk of these corporations against the rights and interests of less developed countries. The growing gaps between social classes within and between nation-states during recent decades are the best examples for the results of such newly established rules.

The economic, cultural, and political globalization of capitalist systems, together with the exclusionary interventions of powerful states and corporations, implies the globalization of social and environmental problems. This in turn actualizes the need for the development of social alertness. The recognition of shared problems could eventually lead to insight about, and even intellectual demands for, shared efforts towards developing explanatory understanding of the totality of glocal social relations. ${ }^{11}$ The growth of world public awareness of the interdependence of many global and local social and environmental problems has been translated into the global field of resistance, despite many intellectual contentions in analyzing the problems and their causes. The multi-dimensional, multisphered, multi-polar, multi-scalar, and multi-subjective nature of globalization requires actors to give up reductionist and dualist perspectives in explaining the events as far as this nature is itself experienced and self-reflectively acknowledged by the actors.

Among the diverse transnationalizing networks of resistance against the interventions by such sources of power into the diverse realms of social subjects, there is a growing mindful convergence that sees the fragmented intrusions as systemic, rooted in the networks of capitalist corporations and elites themselves (see Starr 2000; Danaher and Mark 2003; Yates 2003). 'It is this developing consciousness of the system that more than anything else, characterizes the movement' (Callinicos 2003, 15). However, such a newly created capacity is not free from uncertainties, disputes, and weaknesses.

Involved in the current organizational configuration of the movement, which is shaped around flexible networks of communication, the actors on the one hand experience flexibility

\footnotetext{
${ }^{11}$ For instance, on the issue of global pandemics and public health, Yach and Bettcher reflect such a requirement: 'The transnationalization of disease and health risks will require global awareness, analysis, and action and indicates a need for global cooperation' $(1998,738)$.
} 
and autonomy in representing their own ideas, while on the other they experience uncertainty in defining their relationship with other groups' perspectives. These paradoxical experiences of both positive and negative aspects of the growing globalization from below have shaped new aspirations for poising between a sufficient degree of flexibility and a satisfactory level of certitude (for example, recall the attitude of Irene Santiago, cited in this article). As Melucci (1992) argues, the loss of certainties is the starting point and the potential foundation of a new awareness. In social relations, not everything is subject to the calculus of an absolute rationality. Therefore, ideational diversity and uncertainty can become cognitive bases for a new mode of solidarity (accommodative solidarity).

\section{Conclusion}

As shown in this article, with regard to the recent structural and agential changes, the growing prospects for developing accommodative consciousness questions the reductionist assumptions behind the rival mainstream paradigms such as the materialist and postmaterialist, structuralist and post-structuralist, modernist and post-modernist assumptions. Current global alternative movements, including the alter-globalization trend, are not simply reducible to either soft praxis or hard praxis. Although they carry many paradoxes caused by persisting undigested experiences of past practices, experiencing this uncertainty or confusion itself has resulted in the emergence of new intellectual demands in the field to convey accommodative modes of thought. I have presented a sample of these demands in this article. Rejecting any artificial compromise or unification, these new intellectual demands - though from different points of view—are grounded in the necessity of:

- Articulating integrative visions without sacrificing singularities,

- Affirming collectivities and commons without sacrificing individualities,

- Strategically challenging the system as a whole without ignoring identities and particularities,

- Targeting redistributive and material issues without refraining from the recognition of life-styles and post-material concerns,

- Transforming society and its very basic cultural elements without being trapped into a dilemma of reform or revolution. 
These balances in the practical visions within the alter-globalization movement have been associated with two other parallel extensions in worldviews. The first, as discussed in the second section, is the extension of the Self to the Other, not just by developing imaginary empathies and sympathies, but also through practically developing webs for exchanging particular experiences of all forms of oppression. The second extension of worldviews is rooted in conceptualizing structural complexities of globalization processes in terms of their inherent interdependences, inequalities, and asymmetries.

At the practical level we can conclude that while the 1980s and early 1990s movements provided a field for the improvement of an actor's agency or historical subjectivity ${ }^{12}$, the alter-globalization movement has afforded prospects ${ }^{13}$ for the solidarity of self-defining social subjects. This solidarity is no longer based on self-sacrifice, but rather inclusively accommodates the Other subject and comprehensively recognizes the totality of objective conditions. This situation has had similar implications for the activists' cognition of social reality and goes beyond the dilemmas of both the soft and hard praxes

At the theoretical level, again similar to the 1960-1970s cultural-linguistic turn in both the realm of theory and practice, contemporary processes of both structural and agential changes —namely what is known as globalization from above and from below-have implied significant requirements for modifying sociological studies of current social movements. Whilst accepting that the requirement of these integrative demands for the realm of theory is the subject of controversial arguments and explorations at both the levels of activism and sociological knowledge, the rock-bottom conclusion is that there are greater prospects than ever for developing synthesizing approaches towards overwhelming artificial controversies at the level of theory, i.e. the dilemmas made by dichotomies such as social structuralism/constructionism, infra-structuralism/ super-structuralism, New SMs/ Old SMs, materialism/culturalism. One may call this prospective turn the 'post-dualist turn' in the social theory of collective actions.

\footnotetext{
${ }^{12}$ By this I mean that the 1970s-1980s movements, by focusing on identity and self-regulation demands, have provided the cognitive ground for individuals and communities to identify themselves as the major authentic sources of social change more than before.

${ }^{13}$ By prospects here I mean, 'A mental looking forward; consideration or knowledge of, or regard to something future' (Oxford 2003)
} 


\section{Acknowledgements}

I am grateful for the valuable suggestions of the anonymous reviewers of this article, and I wish to acknowledge helpful comments by Dr. Gail Craswell and Dr. Lawrence Saha.

\section{Reference list \lceil}

Adamovsky, E. 2005, Beyond the World Social Forum: the need for new institutions [online], Open Democracy. Available: http://www.opendemocracy.net/debates/article-6-91-2314.jsp, [Accessed 7 Feb 2005].

Adler, G. \& Mittelman, J. H. 2004, 'Reconstituting “common-sense” knowledge: representations of globalization protests', International Relations, 18, 2, 189211.

Alfaro, V. 2004, 'Social movements facing the processes of globalization: beyond the paradigms of class and identity', Portal [online], 1, 2. Available: http://epress.lib.uts.edu.au/ojs/index.php/portal/article/view/57/0

Anthias, F. 1999, 'Beyond unities of identity in high modernity', Identities-Global Studies in Culture and Power, 6, 1, 121-44.

Ashman, S. 2004, 'Resistance to neoliberal globalization: a case of "militant particularism”?' Politics, 24, 2, 143-53.

Barchiesi, F. 2003, 'Communities between commons and commodities: subjectivity and needs in the definition of new social movements', The Commoner [online], Winter, 6. Available: http://www.commoner.org.uk/barchiesi06.pdf

Beck, U. 2000a, 'The Cosmopolitan perspective: sociology of the second age of modernity', British Journal of Sociology, 51, 1, 79-105. 2000b, What is Globalization?, Polity Press, Malden, MA.

Black Radical Congress 1999, The freedom agenda (FA) of the Black Radical Congress $(B R C)$ [online], BRC National Council. Available: http://www.blackradicalcongress.org/aboutus/freedomagenda.html, [Accessed 30 Nov. 2004].

Burgmann, V. 2003, Power, Profit and Protest: Australian Social Movements and Globalisation, Allen \& Unwin, Crows Nest, N.S.W.

Busby, J. W. 2002, 'Listen! Pay Attention! Transnational Social Movements, Communicative Action and Global Governance', proceedings of conference Critical Perspectives on Global Governance, Amerang, Germany. http://www.georgetown.edu/users/busbyj/cpogg.paper.pdf.

Callinicos, A. 2003, An Anti-Capitalist Manifesto, Polity Press, Cambridge.

Carr, B. 2002 'Labour internationalism and the North American free trade agreement', in Protest and Globalisation: Prospects for Transnational Solidarity, ed(s). J. Goodman, Pluto Press Australia, Annandale, N.S.W., 203-15.

Castells, M. 1983, The City and the Grassroots: A Cross Cultural Theory of Urban Social Movements, University of California Press, Berkeley. 1997, The Power of Identity, Blackwell, Malden, Mass. 2004, The Power of Identity, Blackwell Publishing, Malden; Oxford. 
Cavanagh, J. \& Mander, J. (eds) 2004, Alternatives to Economic Globalization: a Better World is Possible. Berrett-Koehler, A report of the International Forum on Globalization, San Francisco.

Chase-Dunn, C. 2002, 'Globalization from below: toward a collectively rational and democratic global commonwealth', Annals of the American Academy of Political and Social Science, 581, 1, 48-61.

Cohen, R. \& Rai, S.(eds.) 2000a, Global Social Movements, Athlone Press, London; New Brunswick, NJ. . 2000b 'Global social movements: towards cosmopolitan politics', in Global Social Movements, ed(s). R. Cohen \& S. M. Rai, The Athlone Press, London.

Commission on Global Governance 1995a, Issues in Global Governance: papers written for the Commission on Global Governance, Kluwer Law International in association with the Commission on Global Governance, London; Boston. 1995b, Our Global Neighbourhood: the Report of the Commission on Global Governance, Oxford University Press, Oxford; New York.

Connolly, W. E. 2002, Identity, Difference: Democratic Negotiations of Political Paradox, University of Minnesota Press, Minneapolis.

Danaher, K. \& Mark, J. D. 2003, Insurrection: Citizen Challenges to Corporate Power, Routledge, New York; London.

Day, R. J. F. 2004, 'From hegemony to affinity: the political logic of the newest social movements', Cultural Studies, 18, 5, 716-48.

De Angelis, M. 2003, 'Reflections on alternatives, commons and communities or building a new world from the bottom up' [online], The Commoner. Available: http://www.commoner.org.uk/deangelis06.pdf\#search='reflections\%20on\%20al ternative\%20commons', [Accessed 15 Oct. 2005].

Della Porta, D. \& Kriesi, H. 1999 'Social movements in a globalizing world: an introduction', in Social Movements in a Globalizing World, eds D. Della Porta, et al., St. Martin's Press, New York, 3-22.

Dixon, C. 2001 'The roots of my resistance: from rhetoric to reality', in Global Uprising: Confronting the Tyrannies of the 21st Century, ed(s). N. Welton \& L. Wolf, New Society Publishers, Gabriola Island, 12-19.

Eschle, C. 2002, 'Engendering global democracy', International Feminist Journal of Politics, 4, 3, 315-41. 1993 'The making of global citizenship', in Global Visions: Beyond the New World Order, eds J. B. Childs et al., South End, Boston, 39-50. 1995, 'Liberalism at the global level: the last of the independent commissions?' Millennium-Journal of International Studies, 24, 3, 563-78. 1997, 'Resisting “globalization-from-above" through "globalization-frombelow"', new Political Economy, 2, 1, 17-23. 2003 'Globalization-from-bellow: an innovative politics of difference', in Civilizing Globalization: a Survival Guide, ed. R. Sandbrook, State University of New York Press, Albany, 189-205.

2000, Human rights horizons: the pursuit of justice in a globalizing world, Routledge, New York.

Farro, A. L. 2004, 'Actors, conflicts and the globalization movement', Current Sociology / Sociologie Contemporaine, 52, 4, 633-47. 
Fotopoulos, T. 2001, 'Globalization, the reformist left and the anti-globalization 'movement", Democracy \& Nature, 7, 2, 233-80.

George, S. 2001 'Corporate globalization', in Anticapitalism: a Guide to the Movement, eds E. Bircham \& J. Charlton, Bookmarks, London, 11-24.

Goodman, J. (ed.) 2002, Protest and Globalisation: Prospects for Transnational Solidarity. Pluto Press Australia, Annandale, N.S.W.

Gorz, A. 1967, Strategy for Labor: a Radical Proposal, Beacon P., Boston.

Grenfell, D. 2002 'Environmentalism, state power and national interests', in Protest and Globalisation: Prospects for Transnational Solidarity, ed(s). J. Goodman, Pluto Press Australia, Annandale, N.S.W., 108-22.

Habermas, J. 1984, The Theory of Communicative Action, Vol. 1: Reasons and the Rationalization of Society, T. McCarthy, Beacon Press, Boston, MA. 1987, The Theory of Communicative Action, Vol. 2: Lifeworld and System, A Critique of Functionalist Reason, trans., T. McCarthy, Beacon Press, Boston.

Healy, S. 2000, 'IMF/WB/WTO: Fix it or nix it?' Green Left Weekly [online], 402, April 19. Available: http://www.greenleft.org.au/back/2000/402/index.htm,

Held, D. 1995, Democracy and the Global Order: from the Modern State to Cosmopolitan Governance, Stanford University Press, Stanford, Calif. 2004, Global Covenant: the Social Democratic Alternative to the Washington Consensus, Polity, Cambridge.

Held, D. \& Koenig-Archibugi, M. 2003, Taming Globalization: Frontiers of Governance, Polity Press, Cambridge.

Held, D. \& McGrew, A. G. 2002, Globalization/Anti-Globalization, Blackwell Publishers, Malden, MA.

Holden, B. (ed.) 1999, Global Democracy: Key Debates. Routledge, London.

Johnston, J. \& Laxer, G. 2003, 'Solidarity in the age of globalization: lessons from the anti-mai and zapatista struggles', Theory and Society, 32, 1, 39-91.

Keck, M. E. \& Sikkink, K. 1998, Activists beyond Borders: Advocacy Networks in International Politics, Cornell University Press, Ithaca, N.Y.

Kohler, B. \& Wissen, M. 2003, 'Globalizing protest: urban conflicts and the global social movements', International Journal of Urban and Regional Research, 27, 4, 942-51.

Laxer, G. 2001, 'The Movement that dare not speak its name: the return of left nationalism/internationalism', Alternatives, 26, 1, 1-32.

MacEwan, A. 1999, Neo-Liberalism or Democracy? Economic Strategy, Markets, and Alternatives for the 21st Century, Pluto Press; Zed Books, London/ New York.

Martinez, E. 2004 'Racism: the U.S. creation myth and its premise keepers', in Globalize Liberation: how to uproot the system and build a better world, eds D. Solnit, City Lights, San Francisco, CA, 51-60.

McDonald, K. 2002, 'From solidarity to fluidarity: social movements beyond 'collective identity' - the case of globalization conflict', Social Movement Studies, 1, 2, 10928.

McGrew, A. G. (ed.) 1997, The Transformation of Democracy? Globalization and Territorial Democracy. Polity Press, Malden.

Melucci, A. 1989, Nomads of the Present: Social Movements and Individual Needs in Contemporary Society, Temple University Press, Philadelphia. 
1992, 'Liberation or meaning? Social movements, culture and democracy', Development and Change, 23, 3, 43-77.

1995, 'Individualization and globalization: individualisation et globalisation', Cahiers de recherche sociologique, 24, 185-206.

1996, Challenging Codes: Collective Action in the Information Age, Cambridge

U Press, England.

Melucci, A. \& Avritzer, L. 2000, 'Complexity, cultural pluralism and democracy: collective action in the public space', Social Science Information Sur Les Sciences Sociales, 39, 4, 507-27.

Midnight Notes 1998, Introduction to midnight notes 12: one no, many yeses [online], Midnight Notes Collective. Available: http://www.midnightnotes.org/12intro.html, [Accessed 30 Nov 2004].

Midnight Notes Collective 2004 'The new enclosures: planetary class struggle', in Globalize Liberation: how to uproot the system and build a better world, ed(s). D. Solnit, City Lights Books, San Francisco, 61-72.

Moghadam, V. M. 2000, 'Transnational feminist networks: collective action in an era of globalization', International Sociology, 15, 1, 57-85.

Munck, R. 2003, 'Global Social Movements or Sorel in Seattle', proceedings of conference Challenges to the New World Order: Anti-Globalism and CounterGlobalism, International Institute of Social History, Amsterdam. http://www.iisg.nl/research/munck.doc; http://www.theglobalsite.ac.uk/press/401munck.htm.

O'Brien, R., et al. (eds.) 2000, Contesting Global Governance: Multilateral Economic Institutions and Global Social Movements. Cambridge University Press, Cambridge.

Oxford, U. P. 2003, Oxford English Dictionary online [online], Oxford University Press. Available: http://www.oed.com/, [Accessed 1 Oct. 2003].

Pieterse, J. N. 1992 'Emancipations, modern and postmodern', in Emancipations, Modern and Postmodern, ed(s). J. N. Pieterse, Sage Publications, London.

Ponniah, T. \& Fisher, W. F. 2003 'Introduction: the World Social Forum and the reinvention of democracy', in Another World is Possible: Popular Alternatives to Globalization at the World Social Forum, ed(s). W. F. Fisher \& T. Ponniah, Zed Books, London; New York, xix, 364.

Reintjas, C. 2002, What is a Solidarity Economy? [online], Z net. Available: http://www.zmag.org/carolase.htm, [Accessed 12 Nov. 2004].

Reinventing Social Emancipation Website 1999, Reinventing Social Emancipation [online], Centre for Social Studies (CES), University of Coimbra. Available: http://www.ces.fe.uc.pt/emancipa/en/, [Accessed 24 Jan. 2005].

Roman, R. \& Arregui, E. 1998 'Worker insurgency, rural revolt, and the crisis of the Mexican regime', in Rising from the Ashes? Labor in the Age of Global Capitalism, ed(s). E. M. Wood, et al., Monthly Review Press, New York, 12741.

Routledge, P. 2000, 'Our Resistance will be as transnational as capital': convergence space and strategy in globalising resistance', GoeJournal, 52, 25-33.

Rucht, D. 1999 'The transnationalization of social movements: trends, causes, problems', in Social movements in a globalizing world, ed(s). D. Della Porta, et al., St. Martin's Press, New York. 
Sales, R. 2002 'Migrant women, citizenship and political action', in Protest and Globalisation: Prospects for Transnational Solidarity, ed(s). J. Goodman, Pluto Press Australia, Annandale, N.S.W., 91-107.

Salleh, A. 2004 'Global alternatives and the meta-industrial class', in New Socialisms: Futures beyond Globalization, ed(s). R. Albritton, et al., Routledge, London, 201-11.

Santiago, I. M. 2004 'foreword: a fierce struggle to re-create the world', in The World Social Forum: Challenging Empires, ed(s). J. Sen, et al., Viveka Foundation, New Delhi, xiv-xvi.

Sen, J., et al. (eds.) 2004, The World Social Forum: Challenging Empires. Viveka Foundation, New Delhi.

Smith, J. 1997 'Social movements and world politics: a theoretical framework', in Transnational Social Movements and Global Politics, ed(s). J. Smith, et al., Syracuse University Press, Syracuse, 59-77.

Solnit, D. (ed.) 2004, Globalize liberation: how to uproot the system and build a better world. City Lights Books, San Francisco.

Solomon, M. 2002 'International NGOs: towards a global cacophonous democracy', in Protest and Globalisation: Prospects for Transnational Solidarity, ed(s). J. Goodman, Pluto Press Australia, Annandale, N.S.W.

Starhawk 2004 'A Feminist view of global justice', in Globalize Liberation: how to uproot the system and build a better world, ed(s). D. Solnit, City Lights Books, San Francisco, 45-50.

Starr, A. 2000, Naming the Enemy: Anti-Corporate Movements Confront Globalization, Zed, Pluto Press, London.

Steen, G. \& Tryggestad, T. L. 1996, 'Our global neighbourhood: reflections on the report of the global governance commission', Internasjonal Politikk, 54, 1, 85-.

Sturgeon, N. 1999, 'Ecofeminist appropriations and transnational environmentalisms', Identities-Global Studies in Culture and Power, 6, 2-3, 255-79.

Tew, J. 2002, Social Theory, Power and Practice, Palgrave, New York.

Touraine, A. 1971, The Post-Industrial Society; Tomorrow's Social History: Classes, Conflicts and Culture in the Programmed Society, Random House, New York. 1981, The Voice and the Eye, Cambridge University Press, New York, NY. 1985, 'An introduction to the study of social movements', Social Research, 52, 749-787. 2000, Can We Live Together? Equality and Difference, trans. D. Macey, Stanford University Press, Stanford.

Unger, R. M. 1998, Democracy Realized: the Progressive Alternative, Verso, London.

Wainwright, H. 2004 'Foreword: the forum as jazz', in The World Social Forum: Challenging Empires, ed(s). J. Sen, et al., Viveka Foundation, New Delhi, xvi$\mathrm{Xx}$.

Waterman, P. 2003, 'Globalisation from the middle? Reflections from a margin', Parallax Journal: The Web Journal of Ethics and Globalization [online], February, Features. Available: http://www.parallaxonline.org/expglobalmiddle.html

Yach, D. \& Bettcher, D. 1998, 'The globalization of public health, ii: the convergence of self-interest and altruism', American Journal of Public Health, 88, 5, 738-41. 
Yates, M. 2003, Naming the System: Inequality and Work in the Global Economy, Monthly Review Press, New York. 